meaning of the word, autobiographical.W. L. Williamson, Library School, University of Wisconsin-Madison.

Cleveland, William S. The Elements of Graphing Data. Monterey, Calif.: Wadsworth Advanced Books and Software, 1985. 323p. \$18.95 LC 85-10603. ISBN 0-5340-3730-5.

The only negative thing that might be said in connection with this book is that it probably won't be read by even a fraction of the scholars who could benefit significantly from exposure to its content. Cleveland's insights and principles go far beyond the relativity simple problem of creating legible graphics; as he writes in the preface: "This book ... contains graphical methods and principles that are powerful tools for showing the structure of data" (p.1, my italics).

Like maps (with which I am most familiar), graphs are made for two quite different reasons. The first is data analysis, for which the scholar uses the graph to tease out or make explicit relationships among observations for his own benefit. The second is data communication, for which the scholar-analyst has determined what the structure of the data is and wants to communicate it effectively to others. Thus a graph can be both an intermediate working tool and a final product, uniquely efficient for both, superior in many instances to words, numbers, or (even) maps. But in the formal educational curriculum at all levels (including college and graduate school) there is an almost overwhelming bias in favor of acquiring and conveying meaningful relationships among data in verbal or numerical form. Cleveland's book forces one to realize what a serious loss this is for scholarship, even for our culture as a whole.

The Elements of Graphing Data is to graphs what Strunk and White's The Elements of Style is to text; high praise is implied and intended in this parallel. Cleveland's writing style-clear, concise, orderly, authoritative, and commonsensical-suggests that he has more than a passing aquaintance with Strunk and White's classic volume. The publisher has also done well by Cleveland, with attrac- tive, legible type, and a generally well thought out book design.

As to content, the book contains four major sections. The first is a brief introductory discussion about graphs, with an emphasis not so much on their form per se (although he integrates knowledgeably the subject of visual perception with all aspect of graphs) as on the meaning that data can take on in graphed form. Cleveland, a scientist at AT\&T Bell Laboratories, has been studying (and inventing) graphical methods for data analysis and presentation for more than ten years.

The second section is a how-to gem, "Principles of Graph Construction." It should be required reading for all educated human beings.

The third section deals with graphical methods and moves at times quite deeply into the domain of statistics. The nonspecialist can easily browse through this section, taking as much as seems useful.

Throughout the book Cleveland uses real data sets to illustrate copiously his discussion. This has the effect of making the book a fascinating read because he delves into actual scientific questions, e.g., do hamsters who hibernate more live longer? In one case study, Cleveland reviews the complete 1980 volume of Science; the majority of articles (67 percent) contained graphs, almost four hundred in number. Nearly one-half of these graphs were flawed, one-third seriously so (something on the graph was not explained, for example). Cleveland's own illustrations (computer generated) are numerous and clear.

The book closes with an admirable exposition of the principles of graphic perception and cognition that bear on the construction and comprehension of graphs. In some respects it might have been logical and useful for the book to begin with this material, but it probably does take on additional meaning after one has thought intently about graphs for more than two hundred pages.

This book is a gem. Buy it, read it, and urge everyone you know whose job it is to convert raw data to meaningful information to do the same.-Barbara Bartz Petchenik, Cartographic Services, R. R. Donnelley $\mathcal{E}$ Sons, Chicago, Illinois. 


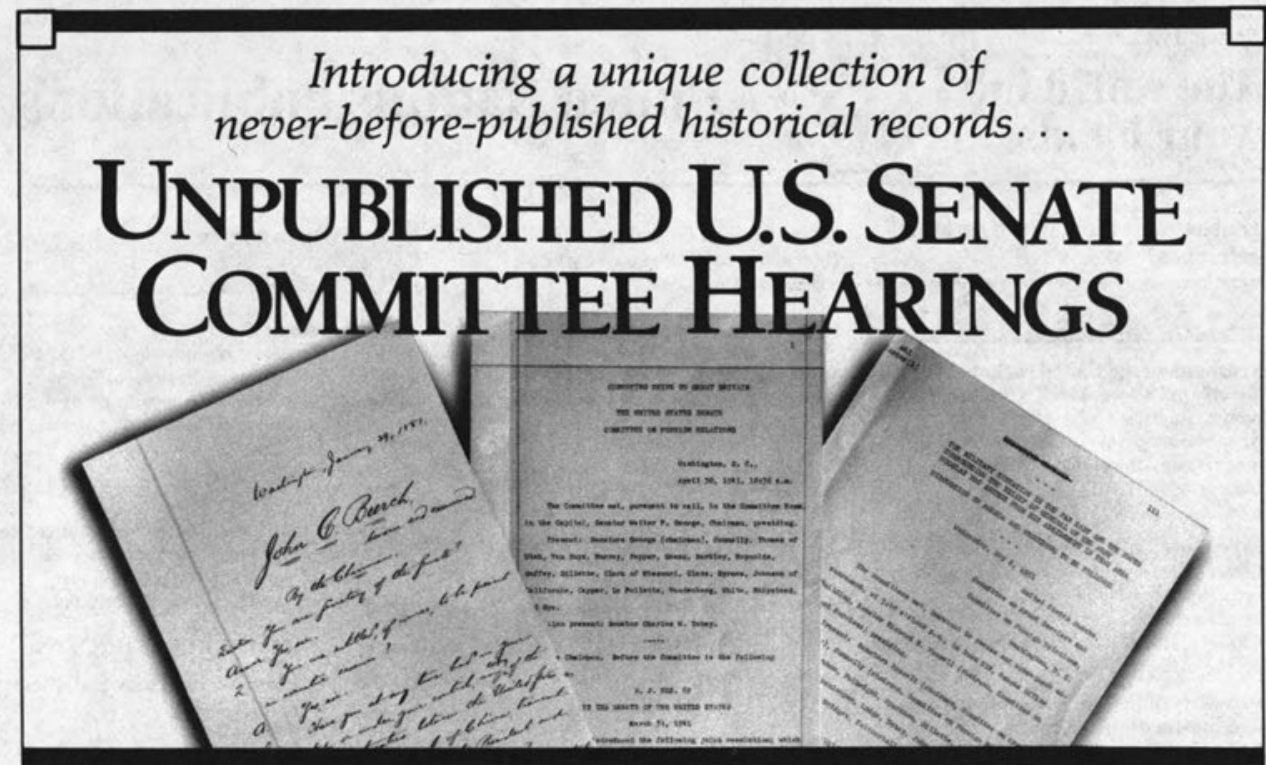

Despite their value, transcripts of many U.S. congressional hearings have never been printed and made available to the public.

\section{Until now.}

CIS has uncovered thousands of long-buried Senate hearings transcripts, and is preparing a major microfiche collection of these materials. A detailed, easy-to-use index will make the collection fully accessible.

Spanning the mid-1800s through 1964, CIS Unpublished U.S. Senate Committee Hearings bridges important gaps in U.S. history.

\section{Voices from the past}

Listen in as the story of America's past is told by:

- Joseph McCarthy • Nelson Rockefeller

- Margaret Chase Smith • John F. Kennedy

- Douglas MacArthur • John Foster Dulles

- Jimmy Hoffa • Edward R. Murrow

- Howard Hughes... and thousands more.

\section{Fresh historical insights}

With this exciting new documents collection, you'll get:

- a new and unique "sense of the times" for more than 100 years of history

- new additions to the legislative histories of dozens of key laws

- a behind-the-scenes look at important congressional investigations
- revealing glimpses of some of the nation's most intriguing public officials.

Write or call for free information

For more information on this important new collection call CIS toll-free to request a free brochure:

\section{$800-638-8380$}

Or fill in and mail the coupon below.

Please rush me more information on the CIS Index to Unpublished U.S. Senate Committee Hearings and companion microfiche collection.

Name

Dept.

Organization

Address

City/State/Zip

MAIL TO:

P- Congressional Information Service, Inc. 4520 East-West Hwy., Suite 800-C Bethesda, MD 20814-3389 Tel. 301-654-1550 


\section{Spring, 1986 \\ The world in your hands. \\ United Nations Publications}

Look at our wide range of serials and reference books.

\section{General}

Yearbook of the United Nations

The principal reference work of the United Nations, providing in single annual volumes, a comprehensive account of the Organization's

wide-ranging activities since 1946.

Latest issue: 1981

E.84.1.1 (ISBN: 92-2-100038-6)

$\$ 75.00$

Everyone's United Nations

Official textbook which contains a definitive history

of the Organization from 1946 to date.

Latest issue: 10th ed

E.85.L.16 (ISBN: 92-1-100273-7) \$14.95 (doth)

E.85.1.16 (ISBN: 92-1-100274-5) \$ 9.95 (paper)

Directory of United Nations Databases and Information Systems

A repertoire of over 600 information databases in $36 \mathrm{UN}$ affiliated organizations. It enables one to see what information and services are available in the United Nations family as a whole and how to obtain detailed information from particular organizations. GV.E.84.0.5. (ISBN: 92-9048-295-8) \$35.00

Statistical

Yearbook of International Commodity Statistics

First issue: 1984

E.84.II.D.22 (ISBN: 92-1-112180-9)

$\$ 45.00$

\section{Demographic Yearbook}

Covers data on population for more than 250

countries and areas. Annual since 1949.

Latest issue: 1983

E/F. 84.XVII.1

(ISBN: 92-1-051030-5)

(ISBN: 92-1-051029-1)

$\$ 90.00$ (cloth)

$\$ 80.00$ (paper)

\section{Statistical Yearbook}

Provides a wealth of data for more than 280

countries and territories on economic and social subjects such as population, agriculture, trade, national income and many others. Annual since 1949.

Latest issue: 1982

EF.84.XVII.1

(ISBN: 92-1-061100-4)

E/F.84.XVII.1

(ISBN: 92-1-061101-2)

$\$ 70.00$ (cloth) $\$ 60.00$ (paper)

\section{Law}

\section{Law of the Sea}

A Select Bibliography

Supplements and updates the bibliographies previously issued by the United Nations Dag Hammarskjold Library.

E.85.V. 2

$\$ 12.00$
United Nations Commission on International Trade Law Yearbook

Annual Issued since 1968.

Included are studies and reports on international trade contracts, international payments, international commercial arbitration and conciliation, the new international economic order. transport law and activities of other onganizations. $\begin{array}{lll}\text { Latest issue: } 1983 & \text { E.85.V. } 3\end{array}$

Yearbook of the International Law

\section{Commission}

Issued since 1949.

Subjects dealt with include arbitral procedures, diplomatic immunities, law of the sea, nationality, law of treaties and rights and duties of States. Latest issue: 1983

vol. I E.84.V.6

. II Pt. 1 E.84.V.7 (ISBN: 92-1-133262-1) \$23.00 vol. II pt. 2 E.84.V.7 (ISBN: 92-1-133331-8) \$12.50

Multilateral Treaties Deposited With The Secretary-General.

Issued annually since 1967 . Lists country

ratifications of treaties and other international instruments.

Status as at 31 December 1984 (ST/LEG/Ser. E/3) E.85.V.4 (ISBN: 92-1-133266-4) $\$ 60.00$

Energy/Environment

Energy in the Eighties

Highlights of the Meeting of the Ad Hoc Group of Energy and Petroleum Experts.

E.83.ILA.16 (ISBN: 92-1-104138-4) $\$ \$ 16.50$

\section{Maintaining Outer Space for Peaceful}

Uses

The compilation of these symposium papers of international law experts represents a contribution to current efforts to safeguard outer space for peaceful uses and a response to the concerns expressed about increasing militarization of outer space.

E.85.III.A.11

$\$ 20.00$

\section{Food as a Human Right}

Focusing on the basic premise that "everyone has a right to food", this book presents the views of an international group of scholars on the economic, social and legal implications of this vitally importan world problem.

E.85.IIL.A.10

$\$ 12.00$

\section{Energy Statistics Yearbook}

Provides a global framework of comparable data on trends and developments in the supply of all forms of energy. Essential to study the outlook in the supply and demand of energy. Hardcover. Latest issue: $1983 \quad$ E/F.85.XVII.9

\section{Business/Economics}

World Economic Survey

Provides an overview of salient developments in the world economy. Attention is drawn to changes in international policies needed to improve the pace of development in developing countries. Annual since 1948.

Latest Issue: 1985

E.85.II.C.1 (ISBN: $92-1-109107-1) \quad \$ 14.50$

Production and Use of Industrial Robots An interesting study on world-wide production and use of industrial robots that includes numerous tables on types of robots and their development in different countries.

E.84.II.E.33 (ISBN: $92-1-116316-1) \quad \$ 25.00$

Yearbook of International Trade Statistics Annual since 1950.

Latest issue: 1982 ( 2 vols)

EF.84.XVII.6 (ISBN: $92-1-061002-4) \quad \$ 80.00$

Handbook of Industrial Statistics 1984

Provides important statistical indicators relevant to drawing international comparisons of the process of industrialization.

EF.84.II.B.8 (ISBN: $92-1-006002-4) \quad \$ 50.00$

\section{Special Offer}

For your order totalling fifty dollars or more that is received by June 30,1986 , you'll receive your FREE personal copy of WORID STATISTICS IN BRIEF Ninth Edition, the official statistical pocketbook of the United Nations. It's a $\$ 5.00$ value.

To order publications, by title and sales number, contact your wholesaler. Or order direct. For more information write for our complete 1986 catalog a the address below.

Publisher's ISBN prefix: (92-1)

\section{United Nations Publications}

Room DC2-853 New York, NY 10017

Palais des Nations 1211 Geneva 10, Switzerland

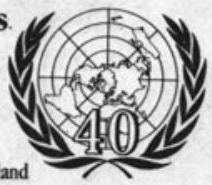

